\section{Do Low Titers of Antibody Against Hepatitis B Surface Antigen Carry a Risk of Viral Reactivation During Immunosuppressive Therapy for Rheumatic Diseases?}

\section{To the Editor:}

I read with great interest the article by Kato, et al regarding hepatitis B virus (HBV) reactivation in patients receiving immunosuppressive therapy for autoimmune diseases ${ }^{1}$. The authors had performed a followup study on 35 patients who were negative for hepatitis B surface antigen ( $\mathrm{HBsAg}$ ) and positive for antibody against hepatitis B core antigen (anti-HBc). During the 8- to 124-week period of followup, 6 patients (17\%) experienced reactivation of viral replication. The authors showed that baseline titers of antibody against HBsAg (anti-HBs) were significantly lower in these patients than in the others (median $2.83 \mathrm{mIU} / \mathrm{ml}$, range $0.24-168.5$ vs median 99.9 $\mathrm{mIU} / \mathrm{ml}$, range $0.00-5343 ; \mathrm{p}=0.036$ ). Accordingly, they suggested that low baseline anti-HBs titers may be a risk factor for viral reactivation in this clinical setting. Among the 6 patients with viral reactivation, however, 1 had a relatively high titer of serum anti-HBs at baseline $(168.5 \mathrm{mIU} / \mathrm{ml})$.

The presence of anti-HBs following natural HBV infection indicates recovery and immunity against reinfection. This antibody can also be acquired as an immune response to active vaccination or passively transferred by administration of hepatitis B immunoglobulin (HBIG). A serum anti-HBs titer of $10 \mathrm{mIU} / \mathrm{ml}$ or greater after immunization is generally considered protective against HBV infection ${ }^{2}$. However, it is unclear whether the presence of anti-HBs is a marker of immunity against reactivation from a resolved HBV infection. To address this issue, I consecutively enrolled patients receiving immunosuppressive therapy for rheumatoid arthritis (RA) who visited our outpatient clinic in September and October of 2011 and examined baseline serological HBV markers prior to therapy. Sixty-two patients were identified as having resolved HBV infection, defined as HBsAg-negative/anti-HBc-positive serology. This patient group consisted of $19(30.6 \%)$ patients with anti-HBs-negative serology $(<10$ $\mathrm{mIU} / \mathrm{ml}), 24(38.7 \%)$ with serum anti-HBs titers between 10 and 100 $\mathrm{mIU} / \mathrm{ml}$, and $19(30.6 \%)$ with serum anti-HBs titers $>100 \mathrm{mIU} / \mathrm{ml}$. The median titer was $25.9 \mathrm{mIU} / \mathrm{ml}$ (range 6.1-140). Disease-modifying antirheumatic drugs that were being used at the time of enrollment and median durations of therapy with these drugs (ranges) were as follows: 59 patients receiving methotrexate (MTX) for 27 (13-57) months, 22 receiving tacrolimus for 18 (11-39) months, 17 receiving infliximab for 9 (2-13) months, 19 receiving etanercept for 9 (6-38) months, 12 receiving tocilizumab for 10.5 (3-17) months, and 8 receiving low-dose prednisolone. Real-time polymerase chain reaction assays (detection threshold $2.0 \log$ copies $/ \mathrm{ml}$ ) were performed at the time of enrollment, and no HBV-DNA was detected in the sera of any patient. Our findings show that the risk of reactivation from resolved HBV infection is low in patients with RA who are receiving immunosuppressive therapy, even in those with anti-HBs-negative serology.

Recently, several reports have emerged regarding the incidence of $\mathrm{HBV}$ reactivation from resolved infection in patients under immunosuppressive therapy for RA and other rheumatic diseases, but the data are somewhat controversial. Most of these reports have concluded that HBV reactivation during this type of immunosuppressive therapy is rare $3,4,5,6,7,8$, but 1 group reported a relatively high incidence of $\mathrm{HBV}$ reactivation ${ }^{9}$, as did Kato, et al. Two studies have indicated a significant decrease in serum anti-HBs titers in rheumatic disease patients with resolved HBV infection receiving anti-tumor necrosis factor- $\alpha$ (anti-TNF- $\alpha$ ) agents, especially those with low baseline anti-HBs titers; nevertheless, no reactivation was observed in these patients ${ }^{3,6}$. One group reported that anti-HBs titers decreased in vaccinated patients during anti-TNF- $\alpha$ therapy as well as in those receiving MTX alone, but viral DNA was not detected in any of these patients at the end of therapy ${ }^{4}$. Lan, et al reported significant decreases in serum anti-HBs titers of RA patients with resolved HBV infection following anti-TNF- $\alpha$ therapy, but no reactivation was observed in this patient population, except in 1 so-called occult infection case in a patient negative for anti-HBs and positive for viral DNA at baseline ${ }^{8}$.
In transplantations of liver grafts from anti-HBc-positive donors, Roque-Afonso, et al ${ }^{10}$ found that no de novo $\mathrm{HBV}$ infections developed in vaccinated recipients or in recipients receiving HBIG, except 1 who had failed to maintain high titers of serum anti-HBs. They have suggested that circulating anti-HBs may prevent reactivation of HBV replication in previously infected liver grafts ${ }^{10}$. When immunity is passively acquired as HBIG, susceptibility to HBV infection returns as anti-HBs titers decline with time. In vaccinated subjects, however, immune memory appears to remain intact for more than 20 years following immunization, which allows anamnestic anti-HBs response upon exposure to $\mathrm{HBsAg}$, even in subjects who have lost this antibody ${ }^{2}$. Thus, a decrease in anti-HBs or even its disappearance does not necessarily indicate loss of protection. This might be true of viral reactivation in rheumatic disease patients with resolved HBV infection, although it should be kept in mind that antigen-specific memory B cell responses may decrease during anti-TNF- $\alpha$ therapy ${ }^{11}$.

The data presented by Kato, et $a l^{1}$ should be interpreted cautiously. It is still debatable whether the maintenance of sufficiently high anti-HBs titers is effective in preventing viral reactivation and resultant de novo hepatitis B in patients with resolved HBV infection. Should HBV vaccination or HBIG administration be considered for patients with resolved HBV infection who are negative for anti-HBs and scheduled to receive immunosuppressive therapy for rheumatic diseases? Additional prospective studies including more patients with longer followup periods will be needed to resolve such questions. Viral DNA appearance in sera has been reported to precede development of de novo hepatitis B by several months ${ }^{12}$. At present, regular monitoring of serum viral DNA seems to be the most rational approach to preventing the devastating outcomes of HBV reactivation during immunosuppressive therapy for rheumatic diseases.

SHUNSUKE MORI, MD, PhD, Clinical Research Center for Rheumatic Disease and Department of Rheumatology, NHO Kumamoto Saishunsou National Hospital, 2659 Suya, Kohshi, Kumamoto 861-1196, Japan. E-mail: moris@saisyunsou1.hosp.go.jp

\section{REFERENCES}

1. Kato M, Atsumi T, Kurita T, Odani T, Fujieda Y, Otomo K, et al. Hepatitis $\mathrm{B}$ virus reactivation by immunosuppressive therapy in patients with autoimmune diseases: Risk analysis in hepatitis B surface antigen-negative cases. J Rheumatol 2011;38:2209-14.

2. Huang LM, Lu CY, Chen DS. Hepatitis B virus infection, its sequelae, and prevention by vaccination. Curr Opin Immunol 2011;23:237-43.

3. Charpin C, Guis S, Colson P, Borentain P, Mattei JP, Alcaraz P, et al. Safety of TNF-blocking agents in rheumatic patients with serology suggesting past hepatitis B state: Results from a cohort of 21 patients. Arthritis Res Ther 2009;11:R179.

4. Vassilopoulos D, Apostolopoulou A, Hadziyannis E, Papatheodoridis GV, Manolakopoulos S, Koskinas J, et al. Long-term safety of anti-TNF treatment in patients with rheumatic diseases and chronic or resolved hepatitis B virus infection. Ann Rheum Dis 2010;69:1352-5.

5. Caporali R, Bobbio-Pallavicini F, Atzeni F, Sakellariou G, Caprioli $\mathrm{M}$, Montecucco C, et al. Safety of tumor necrosis factor alpha blockers in hepatitis B virus occult carriers (hepatitis B surface antigen negative/anti-hepatitis B core antigen positive) with rheumatic diseases. Arthritis Care Res 2010;62:749-54.

6. Tamori A, Koike T, Goto H, Wakitani S, Tada M, Morikawa H, et al. Prospective study of reactivation of hepatitis B virus in patients with rheumatoid arthritis who received immunosuppressive therapy: Evaluation of both HBsAg-positive and HBsAg-negative cohorts. J Gastroenterol 2011;46:556-64.

7. Mori S. Past hepatitis B virus infection in rheumatoid arthritis patients receiving biological and/or nonbiological disease-modifying antirheumatic drugs. Mod Rheumatol 2011;21:621-7. 
8. Lan JL, Chen YM, Hsieh TY, Chen YH, Hsieh CW, Chen DY, et al. Kinetics of viral loads and risk of hepatitis $\mathrm{B}$ virus reactivation in hepatitis B core antibody-positive rheumatoid arthritis patients undergoing anti-tumour necrosis factor alpha therapy. Ann Rheum Dis 2011;70:1719-25.

9. Urata Y, Uesato R, Tanaka D, Kowatari K, Nitobe T, Nakamura Y, et al. Prevalence of reactivation of hepatitis B virus replication in rheumatoid arthritis patients. Mod Rheumatol 2011;21:16-23.

10. Roque-Afonso AM, Feray C, Samuel D, Simoneau D, Roche B, Emile JF, et al. Antibodies to hepatitis B surface antigen prevent viral reactivation in recipients of liver grafts from anti-HBC positive donors. Gut 2002;50:95-9.
11. Anolik JH, Ravikumar R, Barnard J, Owen T, Almudevar A, Milner $\mathrm{EC}$, et al. Cutting edge: anti-tumor necrosis factor therapy in rheumatoid arthritis inhibits memory B lymphocytes via effects on lymphoid germinal centers and follicular dendritic cell networks. J Immunol 2008;180:688-92.

12. Hui CK, Cheung WW, Zhang HY, Au WY, Yueng YH, Leung AY, et al. Kinetics and risk of de novo hepatitis B infection in HBsAg-negative patients undergoing cytotoxic chemotherapy. Gastroenterology 2006;131:59-68.

J Rheumatol 2012;39:6; doi:10.3899/jrheum.120052 